\title{
PCR in Food Analysis
}

\author{
Anja Klančnik1, Minka Kovač2, \\ Nataša Toplak ${ }^{2}$, Saša Piskernik ${ }^{1}$ and Barbara Jeršek ${ }^{1}$ \\ ${ }^{1}$ Dept. of Food Science and Technology, Biotechnical Faculty, University of Ljubljana, \\ ${ }^{2}$ Omega d.o.o., Ljubljana \\ Slovenia
}

\section{Introduction}

The aim of this chapter is to briefly present polymerase chain reaction (PCR)-based technologies for use in the detection and quantification of different microorganisms in foods, with an emphasis on sample preparation and evaluation of results. Furthermore, we indicate the PCR-based methods that are most commonly used for the typing of bacteria, and in the final section we provide examples of PCR application in the detection of unwanted components in foods.

\section{PCR in the analysis of foods}

The microbiological safety of food production is a significant concern of regulatory agencies and the food industry. The most important aspect is to avoid potential negative consequences to human health and economic losses, as well as the loss of consumer confidence.

\subsection{The basics of PCR}

What is PCR? PCR is a technique that is used to amplify a single or a few copies of a piece of nucleic acid, to generate thousands to millions of copies of a particular nucleic acid. It allows much easier characterisation and comparisons of genetic material from different individuals and organisms. Simply stated, it is a "copying machine for DNA molecules". PCR represented a revolution in biological techniques when it was first developed in 1983 by Kary Mullis (Saiki et al., 1985). Mullis won the Nobel Prize for Chemistry in 1993 for his work on the use and development of PCR. PCR allows the biochemist to mimic the natural DNA replication process of a cell in the test-tube.

DNA replication is a biological process in living cells that starts with one double-stranded DNA (dsDNA) molecule and produces two identical (double-stranded) copies of the original dsDNA. Each strand of the original dsDNA serves as a template for the production of the complementary strand. PCR is thus simply the in-vitro replication of dsDNA.

PCR is now a common, simple and inexpensive tool that is used in many different areas, from medical and biological research, to veterinary medicine, hospital analyses, forensic sciences, and paternity testing, and in the food and beverage, biotechnology and 
pharmaceutical industries, among others. PCR is used for different applications, like DNAbased phylogeny, DNA cloning for sequencing, functional analysis of genes, diagnosis of genetic and infectious diseases, human DNA identification, and identification and detection of bacteria and viruses. The principal of PCR is based on thermal cycling, which exploits the thermodynamics of nucleic-acid interactions. The vast majority of PCR machines now use thermal cycling, i.e., alternately heating and cooling of the PCR samples following a defined series of temperature steps. These thermal cycling steps are necessary first to physically separate the two strands in a dsDNA double helix, in the high-temperature process known as DNA melting. At lower temperatures, each strand is then used as a template in dsDNA synthesis, aided by the enzyme DNA polymerase, for the synthesis of the new, complementary, DNA strands.

Each cycle of PCR comprises three different temperature-step processes: denaturation, annealing and elongation. The thermal cycler consists of a metal thermal block with holes for the tubes holding the PCR reaction mixtures. The thermal cycler then raises and lowers the temperature of the block in preprogrammed steps. The first step in thermal cycling, the DNA melting, results in the denaturation of the dsDNA, as it unwinds and separates into single strands (ssDNA) through the breaking of the hydrogen bonding between the base pairs. This step is usually short, at between $10 \mathrm{~s}$ and $30 \mathrm{~s}$ at $92{ }^{\circ} \mathrm{C}$ to $96^{\circ} \mathrm{C}$. The second step is the annealing of the DNA primers to form the complementary sequences to the ssDNA through the formation of hydrogen bonds, which results in two new dsDNAs. These primers are short fragments of DNA that match up to the forming ends of the new DNA sequence of interest. The final step in temperature cycling is the elongation or enzymatic replication of the DNA. In this step, in combination with a positive cation as a catalyst and the required amounts of the complementary deoxynucleotides (dNTPs), the DNA polymerase enzyme is used to start DNA replication at the primer location. Then, to continue the cycling, the dsDNA is heated to separate the strands again, as the whole PCR process begins again. With each PCR cycle, the amount of the DNA segment of interest in a sample thus increases according to the exponent 2 . This exponential increase means that one copy becomes two, which then becomes four, which then becomes eight, and so on with each PCR cycle, assuming $100 \%$ efficiency of template replication. As the PCR cycling progresses, with the DNA generated itself used as a template for further replication, this sets in motion a chain reaction in which the original DNA template is exponentially amplified. Generally speaking, 35 to 40 cycles are needed to provide sufficient DNA in a sample for further analysis.

The essential components in PCR reactions are the polymerase enzyme, primers, dNTPs, buffer and cations. Every PCR reaction contains a thermostable polymerase, as Taq polymerase or DNA polymerase. DNA polymerase was originally isolated from the bacterium Thermus aquaticus, by Thomas Brock in 1965 (Brock \& Boylen, 1973; Chien et al., 1976). T. aquaticus is a bacterium that lives in hot springs and hydrothermal vents, and it has a DNA polymerase enzyme that can withstand the protein-denaturing conditions that are required during PCR (Chien et al., 1976; Saiki et al., 1988). Therefore, this replaced the DNA polymerase from Escherichia coli that was originally used in PCR (Saiki et al., 1985). The optimum temperature for the activity of DNA polymerase is $75^{\circ} \mathrm{C}$ to $80^{\circ} \mathrm{C}$, and it has a halflife of $40 \mathrm{~min}$ at $95^{\circ} \mathrm{C}$ and $9 \mathrm{~min}$ at $97.5^{\circ} \mathrm{C}$, although it can replicate a 1.000-base-pair strand of DNA in less than $10 \mathrm{~s}$ at $72{ }^{\circ} \mathrm{C}$ (Lawyer et al., 1993). Some thermostable DNA polymerases 
have been isolated from other thermophilic bacteria and archaea, such as Pfu DNA polymerase, which has a 'proofreading' activity, and which is being used instead of (or in combination with) Taq polymerase for high-fidelity DNA amplification. The use of a thermostable DNA polymerase eliminates the need for addition of new polymerase enzyme to the PCR reaction during the thermocycling process, and this represents the key to successful PCR.

The DNA polymerase requires a catalyst in the form of divalent cations, as either the magnesium $\left(\mathrm{Mg}^{2+}\right)$ or manganese $\left(\mathrm{Mn}^{2+}\right)$ cations. These cations also serve as a co-factor to help stabilises the two ssDNA strands. The usual concentration of $\mathrm{Mg}^{2+}$ in the $\mathrm{PCR}$ reaction is approximately $2.5 \mu \mathrm{M}$. The right concentration of cations is critical, because at higher concentrations they can promote greater promiscuity of the Taq polymerase.

The primers are oligonucleotides (in PCR, primer pairs are used) that are added as short synthesised DNA fragments that contain sequences that are complementary to the target region of the target DNA molecule. The primers anneal to terminal part of the target sequence that is to be amplified. These primers are key components for the selective and repeated amplification of the target DNA fragments from a pool of DNA, and they are typically 20-25 bases long, and usually not more than 30 bases long (Stock et al., 2009). A given set of primers is used for the amplification of one PCR product. One of the primers anneals to the forward strand and the other to the reverse strand of the DNA molecules during the annealing step. The primers themselves are most commonly synthesised from individual nucleoside phosphoramidites, in a sequence-specific manner. These primers thus readily bind to their respective complementary DNA or RNA strands in a sequence-specific manner, to form duplexes or, less often, hybrids of a higher order. As such, the primers are required for initiation of DNA synthesis, and they thus allow the DNA polymerase to extend the oligonucleotides and replicate the complementary strand. The DNA polymerase, starts replication at the 3 '-end of the primer, and complements the opposite strand. A primer with an annealing temperature significantly higher than the reaction annealing temperature can miss-hybridise and extend the DNA at an incorrect location along the DNA sequence, while at a significantly lower temperature than the annealing temperature, the DNA can fail to anneal and extend at all. Primer sequences also need to be chosen to uniquely select for a region of DNA, and to avoid the possibility of miss-hybridisation to a similar sequence nearby. These primers are thus designed using specific tools, such as the Primer Express software (Life Technologies, Carlsbad, USA), or others. A commonly used method in primer design involves a BLAST search, which is a search tool in the GenBank database, whereby all of the possible regions to which a primer can bind are seen. Also, mononucleotide repeats should be avoided in primers, as loop formation can occur, which can contribute to miss-hybridisation. Primers should also not easily anneal with other primers in the PCR mixture, as this can lead to the production of 'primer dimer' products that can contaminate the PCR mixture. Primers should also not anneal to themselves, as internal hairpins and loops can also hinder annealing with the template DNA. Sometimes degenerate primers are used. These are actually mixtures of similar, but not identical, primers. These can be convenient to use if the same gene is to be amplified from different organisms, as the genes themselves are probably similar, but not necessarily identical. The use of such degenerate primers greatly reduces the specificity of the PCR process. Degenerate primers are widely used and have proven to be extremely useful in the field of microbial ecology. They allow 
for the amplification of genes from microorganisms that have not been cultivated previously, and they allow the recovery of genes from organisms where the genomic information is not available.

In the PCR reaction, the DNA polymerase enzymatically assembles a new dsDNA strand from the DNA building-blocks, the dNTPs, using the ssDNA as a template. These dNTPs are the molecules that when joined together, make up the structural units of RNA and DNA (Bartlett \& Stirling, 2003).

Gel electrophoresis is usually performed following PCR, for analytical purposes. This is a method to separate a mixed population of DNA, RNA or PCR products according to their lengths. These nucleic acid molecules are separated by applying an electric field to move the negatively charged molecules through a particular matrix (agarose, polyacrylamide). After the electrophoresis is complete, the molecules in the gel can be stained to make them visible. DNA can be visualised using dyes that intercalate along dsDNA molecules, whereby the bound dyes fluoresce under ultraviolet light (e.g. ethidium bromide, SYBR Green I). The size of a PCR product is determined with the use of a DNA 'ladder'. This is a solution of DNA molecules of different known lengths that are also used in the gel electrophoresis, and these act as known references to estimate the sizes of the unknown DNA molecules (Robyt \& White, 1990; Sambrook \& Russel, 2001).

\subsection{Principles of quantitative PCR}

Over the last few years, the development of novel agents and instrumentation platforms that enable the detection of PCR products on a real-time basis has led to the widespread adoption of quantitative real-time PCR (qPCR; also known as Q-PCR/qrt-PCR). qPCR is one of the most powerful technologies in molecular biology. Using qPCR, specific sequences within a DNA or cDNA template can be copied, or 'amplified', many thousand-fold, or up to a million-fold. In conventional PCR, detection and quantification of the amplified sequence are performed at the end of the PCR, after the final PCR cycle, and this involves post-PCR analysis (gel electrophoresis and image analysis; as above). In qPCR, the amount of the PCR product is measured at each cycle. This ability to monitor the reaction during its exponential phase enables the user to determine the initial amount of the target with great precision (Holland et al., 1991; Higuchi et al., 1992; 1993). The quantity can be either an absolute number of copies or a relative amount when normalised to the DNA input or to additional normalising genes. The essential components in qPCR are the same as in standard PCR, the only differences are in the detection (fluorescence dye) of the amplified target, and the requirement for a specific instrumentation platform.

The qPCR instrumentation consists of a thermal cycler, a computer, optics for fluorescence excitation and emission collection (a fluorimeter), and the data acquisition and analysis software. The first qPCR machine was described in 1993 by Higuchi et al. qPCR monitors the actual progress of the PCR and the nature of the amplified products through the measurement of fluorescence. The benefit of qPCR is the use of a PCR 'master mix' (a mix containing all of the essential components for the qPCR). qPCR reactions are usually successfully carried out under the same reaction conditions, or under universal conditions. Also, the use of passive reference dyes is recommended (usually the ROXTM dye), to normalise for non-PCR-related fluctuations in the fluorescence signals. 
The amplified target can be detected in two different ways: first, with non-specific fluorescent dyes that intercalate with any dsDNA; and second, with sequence-specific DNA probes that consist of oligonucleotides that are labelled with a fluorescent reporter dye that allows binding to, and thus detection of, only the target DNA that contains the probe sequence. With the use of non-specific fluorescent dyes an increase in the qPCR product during the qPCR leads to an increase in the fluorescence intensity that is measured at each cycle, thus allowing the dsDNA concentrations to be quantified. However, if the specify of the qPCR is limited as these dyes will bind to all of the dsDNA produced within the qPCR. Thus non-specific fluorescent dyes will measure not just the desired qPCR products, but also non-specific PCR products (e.g. including primer dimers). This can potentially interfere with, or prevent, the accurate quantification of the intended target sequence.

More specific detection is possible with the use of sequence-specific DNA probes, which detect only the target DNA sequence. The use of these probes significantly increases the detection specificity and the sensitivity of the method, and it also allows quantification even in the presence of non-specific DNA amplification. A variety of different probes are now used (Molecular Beacon, Scorpion probe, and others), although those most commonly used are hydrolysis probes (TaqMan probes). A hydrolysis probe is labelled with a fluorescent reporter at its 5 '-end and with a molecule known as the 'quencher' at its opposite end. When the probe is intact, the close proximity of the reporter and the quencher prevents the detection of the reporter fluorescence. This quenching of the reporter fluorescence by the quencher occurs through the process of fluorescence resonance energy transfer. As the PCR reaction proceeds, during the annealing stage, the primers and the probe are hybridised to the complementary ssDNA strand and the reporter fluorescence remains quenched. Following initiation of polymerisation of the new DNA strand from the primers, the DNA polymerase then reaches the probe, and its 5'-3'exonuclease activity degrades the probe, which physically breaks the reporter and quencher proximity (Lyamichev et al., 1993). The released emission of the separate fluorescent reporter can then be detected after excitation with an appropriate source of light, which results in an increase in fluorescence. Of note, probes with different fluorescence dye labels can be used in multiplex assays for the detection of several target nucleic acids in a single $\mathrm{qPCR}$ reaction.

To understand the benefits of qPCR, an overview of the fundamentals of PCR is necessary. At the start of a PCR reaction, the reagents are in excess, the template and product are at low enough concentrations that the product renaturation does not compete with the primer binding, and the amplification proceeds at a constant, exponential, rate. The point at which the reaction rate ceases to be exponential and enters a linear phase of amplification is extremely variable, even between replicate samples. Then, at a later cycle, the amplification rate drops to near zero (reaches a plateau), and little more PCR product is made. For the sake of accuracy and precision, it is necessary to collect quantitative data at a point in which every sample is in the exponential phase of amplification. Analysis of the reactions during the exponential phase at a given cycle number should theoretically provide several orders of magnitude of dynamic range, which would normally be from 5 to 9 orders of magnitude of quantification. The fluorescence of the PCR products for each sample in every cycle is detected and measured in the qPCR machine, and its geometric increase that corresponds to 
the exponential increase of the product is used to determine the threshold cycle in each reaction. This collected fluorescence for a positive $\mathrm{qPCR}$ reaction is actually seen as a sigmoidal amplification plot, where the fluorescence is plotted against the number of cycles. The different parts of the amplification curves are important. The baseline represents the noise level in the early cycles, and this is subtracted from the fluorescence obtained from the PCR products. The threshold is a level that is adjusted to a value above the baseline that must be located in the exponential phase of the amplification plot, and the threshold cycle $\left(\mathrm{C}_{\mathrm{T}}\right)$ is the cycle at which the amplification plot crosses the threshold (Bustin \& Nolan, 2004; Bustin, 2004; Logan et al., 2009; Raymaekers et al., 2009). A standard curve can be derived from the serial dilutions of positive sample. The slopes of the standard curves (S) and correlation coefficients $\left(\mathrm{R}^{2}\right)$ are used to estimate the qPCR efficiency (E) and to assess the linear range of detection and reliability of the qPCR assays used (Bustin, 2004; Rutledge \& Côté, 2003).

There are numerous applications for qPCR. It is commonly used for both basic and diagnostic research. Diagnostic qPCR is used to rapidly detect nucleic acids that are diagnostic of, for example, infectious diseases, cancers or genetic abnormalities.

\subsection{Food preparation and PCR-based detection of food-borne bacteria}

Conventional methods for the detection of pathogens and other microorganisms are based on culture methods, but these are time consuming and laborious, and are no longer compatible with the needs of quality control and diagnostic laboratories to provide rapid results (Perry et al., 2007). In contrast, PCR is a specific and sensitive alternative that can provide accurate results in about $24 \mathrm{~h}$, and this thus opens a lot of possibilities for the direct detection of microorganisms in a food product. The targets in the foods are DNA or RNA of pathogens, as spoilage microorganisms; DNA of moulds that can produce mycotoxins; DNA of bacteria that can produce toxins; and DNA associated with trace components (e.g. allergens, like nuts) or unwanted components for food authenticity (e.g. cows' milk in goats' milk cheese). However, when PCR is applied for detection of pathogens in food products, some problems can be encountered, although many of these can be solved by the use of suitable sample preparation methods (Lantz et al., 1994; Hill, 1996).

\subsubsection{Sample preparation}

Sample preparation is an important factor for PCR analysis and PCR sensitivity, especially in the direct implementation of PCR to complex foods. Sample treatment prior to PCR is also a complex issue. This mainly arises because of the need to concentrate the target DNA or RNA into the very small volumes used, which are usually $1 \mu \mathrm{l}$ to $10 \mu \mathrm{l}$ for PCR samples, and the presence of any PCR inhibitory substances in the samples (Rådström et al., 2004). Preparation of the sample is divided into the collection of the food sample, separation and concentration of any cells in the sample, treatment of these cells (lysis, for cell-wall decomposition), and isolation and purification of DNA (Lantz et al., 1994). The stomacher is the most widely used treatment technique for the recovery of microorganisms in food samples (Jay \& Margitic, 1979). Compared to mechanical methods, hand massaging is a milder homogenisation technique (Kanki et al., 2009). 
The objectives of sample preparation are to exclude PCR-inhibitory substances that can reduce the amplification capacity and efficiency, to increase the concentration of the target organism/DNA according to the PCR detection limit or quantification range, and to reduce the amount of the heterogeneous bulk sample for the production of a homogeneous sample for amplification, to insure reproducibility and repeatability (Rådström et al., 2004). Many sample-preparation methods are laborious, expensive, and time consuming, or they do not provide the desired template quality. Since sample preparation is a complex step in diagnostic PCR, a large variety of methods have been developed, and all of these methods can affect the PCR analysis differently, in terms of the specificity and sensitivity (Lantz et al., 2000; Germini et al., 2009).

\subsubsection{Target-cell separation and sample concentration}

The first challenge is to chose optimal sample collection and preparation protocols, and to know whether the pathogen contaminates the foods at high levels, or whether it will be necessary to amplify the bacteria with an enrichment culture, or to use other techniques.

The basic processes of the separation and concentration of the cells are centrifugation (physical separation of suspended particles from a liquid medium) and filtration (including ultrafiltration; physical separation of suspended particles by retention on the filtration medium). The homogeneity of a sample can also differ according to the kind of biological matrix from where it originates. Many sample preparation methods use multiple combinations of these basic processes, which can significantly reduce the presence of inhibitors while increasing the PCR sensitivity and specificity. Further modifications to these physical methods have been used, such as aqueous two-phase systems, buoyantdensity centrifugation, differential centrifugation, filtration and dilution (Lantz et al., 1996; Lindqvist et al., 1997; Rådström et al., 2004; McKillip et al., 2000; Uyttendaele et al., 1999). Density media, such as Percoll (Pharmacia, Uppsala, Sweden) (Lindqvist et al., 1997) and BactXtractor (Quintessence Research AB, Bålsta, Sweden) (Thisted Lambertz et al., 2000), have been used to concentrate the target organism and to remove PCR-inhibitory substances of different densities. After this treatment, whole cells can be obtained, which can then be used directly as PCR samples. However, if components of the sample matrix have the same density as the cells, these can remain to inhibit the DNA amplification. An advantage of density centrifugation is that the target organism is concentrated, which allows a more rapid detection response. Furthermore, these methods are relatively user friendly (Rådström et al., 2004).

Alternatively, many sample treatment methods have been developed specifically for one type of organism and/or for a particular matrix, and studies have indicated that individual methods can work better for one organism than another. The flotation method, which is based on traditional buoyant density centrifugation, can concentrate the target cells and simultaneously separate them from PCR-inhibitory substances, the background flora and particles from the sample matrix, and it can reduce false-positive PCR results due to DNA from dead cells (Wolffs et al., 2004; 2007). More recent developments here include the concept of matrix solubilisation and the use of bacteriophage-derived capture molecules that are immobilised on beads (Mayrl et al., 2009; Aprodu et al., 2011). 
However, pre-PCR processing methods without culture enrichment, such as flotation immunomagnetic separation and filtration, have a quantification limit of approximately $10^{2}$ $10^{3} \mathrm{CFU} / \mathrm{mL}$ or $\mathrm{g}$ of sample, due to the loss of target material during sample preparation and the small volumes analysed (Wolfs et al., 2004; 2007; Löfström et al., 2010; Warren et al., 2007). This loss is usually still too high, as most samples in the food production chain are contaminated with something like $10^{2}$ microorganisms/g (Krämer et al., 2011). Therefore, the optimal enrichment should inhibit the growth of background flora, while simultaneously recovering and multiplying the sublethally damaged cells in a standardised manner. An enrichment culture can amplify bacterial cells and PCR can detect the bacteria by sample collection of bacteria from an enrichment broth, extraction of DNA from the bacterial cells, and then PCR (Knutsson et al., 2002).

Most PCR-based assays currently applied to food samples include a pre-enrichment step, which can be $18 \mathrm{~h}$ or more, to increase the cell numbers while diluting any potential PCR inhibitors in the food matrix being sampled. There are also numerous reports of the successful application of PCR-based assays to samples enriched for $6 \mathrm{~h}$. Recently, Krämer et al. (2011) presented a novel strategy to enumerate low numbers of Salmonella in cork borer samples taken from pig carcasses as a first concept and proof-of-principle for a new sensitive and rapid quantification method based on combined enrichment and qPCR. The novelty of this approach is in the short pre-enrichment step, where for most bacteria, growth is in the log phase. A number of commercial PCR-based kits are also available; e.g., the BAX system developed by Qualicon recommends short culture-based enrichment of the food sample and PCR amplification with gel-based detection of the PCR products (Stewart \& Gendel, 1998). Increasingly, alternative methods have been suggested, such as immunomagnetic separation by magnetic beads coated with antibodies (Lantz et al., 1994; Hallier-Soulier \& Guillot, 1999).

\subsubsection{Treatment of cells and DNA extraction}

DNA or RNA extraction is the first step in the analysis process, and the sample quality is probably the most important component to ensure the reproducibility of the analysis and to preserve the biological meaning (Bustin \& Nolan, 2004; Postollec et al., 2011). Preparation of the template from cells requires lysis (rupture) of the cells (or viruses), to release the DNA or RNA (Lee \& Fairchild, 2006). The DNA molecules inside the cell nucleus need be released from the cell by digestion of the cell walls (cell lysis) (Brock, 2000). The appropriate method for cell lysis is usually chosen according to the PCR detection limit, and the rapidity, preparation simplicity, and demand (Klančnik et al., 2003). The effectiveness of this nuclear extraction depends on several features of the bacterial cell wall, and the treatment that is used can be thermal, chemical, detergents, solvents, mechanical, osmotic shock or the action of enzymes.

Nowadays, it is relatively easy to isolate DNA at very high qualitative and quantitative yields. Most procedures use commercial extraction kits, and depending on the food matrix, these can provide satisfactory results as supplied, or after some modifications. Different commercial kits are also available for biochemical DNA extraction, such as Dr. Food ${ }^{\mathrm{TM}}$ (Dr. Chip Biotech Inc., Miao-Li, Taiwan), PrepMan (Life Technologies, Carlsbad, USA) (Dahlenborg et al., 2001), Purugene (Gentra Systems Inc., Minneapolis, MN, USA) (Fahle \& 
Fisher, 2000), QIAamp ${ }^{\circledR}$ (Qiagen, Valencia, CA, USA) (Freise et al., 2001), AccuProbe (GneProbe, San Diego, CA, USA), Gene-Trak (Gene-Trak Systems Corp., Hopkinton, MA, USA), BAX (Quallcon Inc., Wilmington, DE) (Bailey, 1998), Probelia (Sanofi-Daignostics Pasteur, Marnes-la-Coquette, France), and TaqMan (Life Technologies, Carlsbad, USA). A broad reactive TaqMan assay has also been reported for the detection of rotavirus serotypes in clinical and environmental samples (Jothikumar et al., 2009). In contrast to DNA, intact RNA extraction is more laborious, especially when from complex or fatty food matrices. Some extraction methods that are compatible with subsequent reverse transcription qPCR have been developed for various foods (de Wet et al., 2008; Ulve et al., 2008). Due to fast degradation, RNA has to be analysed rapidly.

The final stage of sample preparation (isolation and purification of the DNA) can be used with a combination of ultracentrifugation and purification by chromatography, extraction with phenol-chloroform, precipitation with ethanol, and treatment with enzymes (e.g. lizocim). The most useful method of removing the remains of other admixtures while also concentrating the sample is extraction with organic solvents and ethanol precipitation of DNA (Steffan \& Atlas, 1991).

\subsubsection{PCR-based detection of food-borne bacteria}

There are numerous PCR-based methods for the detection of microorganisms cited in the scientific literature. There are also a number of commercially available PCR-based assays that have the convenience of providing most of the reagents and controls that are needed to perform the assay, and which appear to have high sensitivity for detecting microorganism contamination. Some examples are given in Table 1.

\subsubsection{PCR inhibition}

The use of conventional and qPCR can be restricted by inhibitors of PCR. This is particularly so when the techniques are applied directly to complex biological samples for the detection of microorganisms, such as clinical, environmental and food samples. PCR inhibitors can originate from the sample itself, or as a result of the method used to collect or to prepare the sample. Either way, inhibitors can dramatically reduce the sensitivity and amplification efficiency of PCR (Rådström et al., 2008). Inhibition of qPCR presents additional concerns, as slight variations in amplification efficiencies between samples can drastically affect the accuracy of template quantification (Ramakers et al., 2003).

\subsubsection{Types of PCR inhibitors}

Food samples produce some of the major problems associated with the use of PCR assays due to various PCR inhibitors that can be found in them. Furthermore, it is imperative to provide a method that has a flexible protocol that can be applied to numerous matrix types to efficiently remove these inhibitory substances that interfere with PCR amplification of the intended target. These PCR inhibitors can originate from the original sample or from sample preparation prior to PCR (Table 2).

PCR can be inhibited by inactivation of the thermostable DNA polymerase, degradation or capture of the nucleic acids, and interference with cell lysis (Rossen et al., 1992; Wilson, 1997; 

isolation

Milk, raw minced

beef, cold smoked Yersinia

sausage, carrots, raw enterocolitica

fish

Enrichment: tryptone soy broth with added $0.6 \%$ yeast extract. Incubation: $18-20 \mathrm{~h}$ at $25^{\circ} \mathrm{C} /$ DNeasy ${ }^{\circledR}$ Blood and Tissue Kit (Qiagen)

Salmonella Agona, Enrichment: phosphate-buffered

Chicken breast skin Salmonella Enteritidis peptone water. Incubation: $24 \mathrm{~h}$ at $37^{\circ} \mathrm{C} /$ boiling with Triton- $X$

S. enterica, E. coli Enrichment: tryptone soy broth

Liquid eggs, infant
Pasteurized liquid egg

O157:H7,

L. monocytogenes Scott A

Meat, smoked fish,

and dairy products, S. aureus dressing, crème.

Ground or minced beef, beef burgers, steak tartare, brunch Enteritidis, beef, chicken juice. L. monocytogenes

Campylobacter

Chicken skin rinse jejuni,

Salmonella Enteritidis formula.

B. cereus

B. cereus

E. coli $\mathrm{O} 157: \mathrm{H7}$

Incubation: $15 \mathrm{~h}$ at $37^{\circ} \mathrm{C} /$ Chelex100 $10 \mathrm{CFU} / 25 \mathrm{~g}$ v

Resin (Sigma) and Wizard® DNA egg Clean-Up system (Promega)

Selective enrichment: Modified

Giolitti and Cantoni broth.

Incubation: $18 \mathrm{~h}$ at $37^{\circ} \mathrm{C} /$ boiling

$10^{\circ} \mathrm{CFU} / 10 \mathrm{~g}$ with Triton X-100

Enrichment: Universal enrichment broth. Incubation: $6 \mathrm{~h}$ or $20 \mathrm{~h}$ at 37

${ }^{\circ} \mathrm{C} /$ PrepMan Ultra sample preparation reagent (Life Technology)

$2.1-12 \mathrm{CFU} / 1 \mathrm{C}$ after $6 \mathrm{~h}$ of enr $1.6 \mathrm{CFU} / 10 \mathrm{~g}$ a enrichment

Flotation method for cell separation/ MagNa Pure system $3 \times 10^{3} \mathrm{CFU} / \mathrm{mI}$ automated DNA extraction (Roche)

No enrichment, direct extraction of DNA/ DNeasy Tissue kit (Qiagen) $40-80 \mathrm{CFU} / \mathrm{m}$ Activated charcoal coated with

Lettuce system (Promega) 
Kainz, 2000; Opel et al., 2010). False-negative results can also occur because of degradation of the target nucleic acid sequences in the sample. The problem can increase with the isolation of bacteria and/or the bacterial DNA directly from a food matrix, with no single sample preparation protocol known to work for every application. When the target of the PCR is microorganisms, an enrichment step can be included if they are present in very low numbers, although most enrichment broths and selective agars contain substances that inhibit the PCR. The important step is to wash the cells collected from an enrichment or agar plate by pelleting them using centrifugation, removing the supernatant, and resuspending the cells in saline or water for the DNA extraction (Lee \& Fairchild, 2006). A good sample preparation protocol will focus on the collection of the bacteria, the removal of potential inhibitors in the foodstuff or culture medium, and the concentration of the extracted DNA. Of note, PCR inhibitors are found in all food types, including meat, milk, cheese and spices (Wilson, 1997).

\begin{tabular}{|c|c|c|}
\hline Sample & PCR inhibitor & Example references \\
\hline $\begin{array}{l}\text { DAIRY } \\
\text { Milk (raw, skimmed, pasteurised, dry), } \\
\text { cheese (dry, soft). }\end{array}$ & $\begin{array}{l}\text { Fat, protein, } \\
\text { calcium, } \\
\text { chelators, dead } \\
\text { cells }\end{array}$ & $\begin{array}{l}\text { Kim et al., 2001; } \\
\text { McKillip et al., 2000; } \\
\text { Rådström et al., } 2004\end{array}$ \\
\hline $\begin{array}{l}\text { MEAT } \\
\text { Chicken (meat, carcass rinse, skin } \\
\text { homogenates, whole leg, sausage, } \\
\text { muscle); turkey (leg, muscle, skin, } \\
\text { internal organs); beef (ground, mince, } \\
\text { roast); pork (ham, minced, raw whole } \\
\text { leg, ground, sausage, meat rolls). }\end{array}$ & $\begin{array}{l}\text { Fat, protein, } \\
\text { collagen (blood) }\end{array}$ & $\begin{array}{l}\text { Uyttendaele et al., 1999; } \\
\text { De Medici et al., 2003; } \\
\text { Hudson et al., 2001; } \\
\text { Whitehouse \& Hottel, } \\
\text { 2007; } \\
\text { Silva et al., } 2011\end{array}$ \\
\hline $\begin{array}{l}\text { SEAFOOD } \\
\text { Fish (cakes, pudding, marinated, sliced); } \\
\text { salmon (smoked), shrimps, shellfish } \\
\text { (muscles, oysters). }\end{array}$ & $\begin{array}{l}\text { Phenolic, cresol, } \\
\text { aldehyde, } \\
\text { protein, fat }\end{array}$ & Agersborg et al., 1997 \\
\hline
\end{tabular}

Table 2. PCR inhibitors in dairy, meat and seafood samples.

Many potential inhibitors of PCR have not been identified, although some are indeed known. For example, milk contains high levels of cations $\left(\mathrm{Ca}^{2+}\right)$, proteases, nucleases, fatty acids, and DNA (Bickley et al., 1996). Studies have shown that high levels of oil, salt, carbohydrate, and amino acids have no inhibitory effects; while casein hydrolysate, $\mathrm{Ca}^{2+}$, and certain components of some enrichment broths are inhibitory for PCR. In addition, haem, bile salts, fatty acids, antibodies, and collagen are PCR inhibitors that can be found in meat and liver samples (Lantz et al., 1997) (Table 2). These inhibitors all have variable effects on the PCR reaction, although in general they will make it more difficult to detect low numbers of bacteria or viruses (Lee \& Fairchild, 2006).

Another important source of inhibitors of PCR is the materials and reagents that come into contact with the samples during their processing or the DNA purification. These include 
excess $\mathrm{KCl}, \mathrm{NaCl}$ and other salts, ionic detergents like sodium deoxycholate, sarkosyl and sodium dodecyl sulphate, ethanol, isopropanol, phenol, xylene, cyanol, and bromophenol blue, among others (Weyant et al., 1990; Beutler et al., 1990; Hoppe et al., 1992).

\subsubsection{Approaches to overcome inhibition}

When PCR inhibition is suspected, the simplest course of action is to dilute the template (and thus also any inhibitors), and to take advantage of the sensitivity of PCR. Inhibition is problematic in many applications of PCR, particularly those involving degraded or low amounts of template DNA, when simply diluting the extract is not desirable. In standard PCR experiments, negative results or unexpectedly low product yields can be indicative of inhibition, provided that the template is known to be present; alternatively, a known amount of non-endogenous DNA can be added to a sample and amplified as an internal positive control. These controls can be used in qPCR, providing quantitative assessments of their performance. Based on modelling individual reaction kinetics and/or on the calculation of amplification efficiency, qPCR also allows inhibited samples to be identified without additional internal positive-control amplifications (Wilson, 1997; King et al., 2009).

The use of a DNA polymerase that is less susceptible to the effects of inhibitory substances is a possible solution to some PCR problems. For example, a number of the newer polymerases, such as Tfl and rTth, are more reliable than Taq polymerase when using PCR templates prepared from meat or cheese samples (Al-Soud \& Rådström, 2000). Moreover, the activity of the DNA polymerases in the presence of inhibitors can be improved with the use of some facilitators, such as bovine serum albumin, dimethyl sulfoxide, Tween 20, Triton-X and betaine (Kreader, 1996; Pomp \& Medrano, 1991; Al-Soud \& Rådström, 2000; Rådström et al., 2004; Wilson, 1997).

\subsection{PCR-based typing methods}

Characterisation of microbial isolates below the species level generally involves the determination of the strains. Typing methods that describe the intraspecies variability of an organism can be important for many reasons: searching for the origin of an infectious disease outbreak (i.e. the contaminated food); relating individual cases to an outbreak; studying differences in pathogenicity, virulence and biocide resistance; seeking ways for food contamination or microbial source tracking; and selecting starter cultures. Over the last 25 years, the development of different molecular techniques for the study of microbial genomes has led to a large increase in the methods for typing microorganisms. The most ideal method is DNA sequencing, which allows the precise differentiation of strains. However, as this is still technically demanding and relatively expensive, many other DNA-based typing methods are used. Some of these can be used with PCR analyses, as follows.

\subsubsection{Amplification profiling}

Across any single microbial species, different genes can be particularly variable, and hence they can be used to determine the strain within the microbial species. Multiplex PCR 
(mPCR) offers one of the possibilities for the screening of different genes. mPCR provides simultaneous analysis of different genes that can be associated with virulence, toxins, antimicrobial resistance, or other properties of different strains. The presence/absence of different genetic factors can be screened for by $\mathrm{MPCR}$, which can then provide the differentiation of strains. The analysis of $\mathrm{mPCR}$ amplicons can be performed with gel electrophoresis or directly by qPCR.

Akiba et al. (2011) applied mPCR to the identification of the seven major serovars of Salmonella; i.e., Typhimurium, Choleraesuis, Infantis, Hadar, Enteritidis, Dublin and Gallinarum. For this mPCR, they included the Salmonella-specific primers from the invA gene and serovar-specific primers. Using the primers that target six virulence genes (fliC, stx1, stx2, eae, rfbE, hlyA) in the mPCR, this allowed differentiation of the E. coli O157:H7 strains from the O25, O26, O55, O78, O103, O111, O127 and O145 E. coli serotypes (Bai et al., 2010). Yersinia enterocolitica strains have also been differentiated using $\mathrm{mPCR}$, according to the presence or absence of genes that encode virulence-associated properties, by targeting the ystA, ail, myfA and virF genes (Estrada et al., 2011). mPCR was developed in a study by Kérouanton et al. (2010) as a rapid alternative method to Listeria monocytogenes serotyping. Staphylococcus aureus strains were typed with a system that used three mPCRs based on the nucleotide sequences of the coa genes (Sakai et al., 2008). This system allowed discrimination between eight main staphylocoagulase types (I-VIII) and three sub-types (VIa-VIc), and this represents a rapid method that can be used as an epidemiological tool for $S$. aureus infection. $S$. aureus strains isolated from different food samples were characterised according to the presence of genes encoding four enterotoxins (SEA, SEB, SEC and SED) (Trnčíková et al, 2010). Differentiation of enterotoxinogenic Bacillus cereus isolates has been achieved using three mPCRs that targeted first $h b l$, nhe, ces and cytK1, and the the $\mathrm{Hbl}(h b l C, h b l D, h b l A)$ and Nhe genes (nheA, nheB, nheC) (Wehrle et al., 2009).

\subsubsection{Amplified fragment length polymorphism}

Amplified fragment length polymorphism (AFLP) consists of five steps (Savelkoul et al., 1999). First, microbial DNA is digested with restriction enzymes (for example EcoRI and MseI), to produce many restriction fragments. Next, there is the ligation of adaptors to correspond to the free ends of the restriction fragments. These adaptors contain sequences that are complementary to the restriction enzyme sites and these sequences are used as targets for PCR primer binding and the subsequent amplification of the restriction fragments. The PCR then uses selective primers that usually have 1-3 additional nucleotides on their 3 -ends. Each nucleotide added to the primer reduces the number of PCR products. Polyacrylamide gel electrophoresis usually yields a pattern of 40 to 200 bands. Improvements in AFLP was also obtained by using fluorescently labelled primers (e.g. $\mathrm{FAM}^{\mathrm{TM}}$, ROX ${ }^{\mathrm{TM}}$, JOETM, TAMRA ${ }^{\mathrm{TM}}$ ) for the detection of fragments in an automatic sequencer with a genetic analysis system and size standards, which can automatically analyse these fragments. This provides standardisation of the fragment sizes and facilitates identification of the polymorphic bands.

Hahm et al. (2003) analysed a total of 54 strains of E. coli that were isolated from food, clinical and faecal samples. Here they indicated that AFLP was not as good as pulsed-field 
gel electrophoresis to determine outbreak origins. In contrast, Leung et al. (2004) showed that AFLP analysis can provide discrimination of E. coli isolates from bovine, human and pig faecal samples although they used the same restriction enzymes (MseI and EcorI) as Hahm et al. (2003). In another study, Lomonaco et al. (2011) applied AFLP for the typing of 103 L. monocytogenes strains isolated from environmental and food samples. They used two sets of restriction enzymes (BamHI/EcoRI for AFLP I, and HindIII/HhaI for AFLP II), indicating that only with the second set of restriction enzymes and the corresponding adaptors and primers could all of the strains be typed and differentiated. AFLP has also been used for taxonomic studies, and Jaimes et al. (2006) suggested that according to AFLP fingerprinting of Clostridium spp. strains, two new species could be defined in this genus. Kure et al. (2003) used AFLP for typing Penicillium commune and Penicillium palitans strains isolated from different cheese factories (air, equipment, plastic film, brine, milk) and samples of semi-hard cheese, through which they demonstrated that the most critical point of unwanted contamination of the cheese was the air in the wrapping room.

\subsubsection{Random amplified polymorphic DNA PCR}

Random amplified polymorphic DNA (RAPD)-PCR involves PCR amplification of 'random' fragments of DNA with arbitrarily chosen primers that are selected without the knowledge of the sequence of the genome to be typed (Williams et al., 1990). These primers are generally 6-10 base pairs long and the amplification is usually run under low-stringency conditions. The primer can be expected to anneal to many sites in the DNA, and when two correctly oriented primers are close enough, the intervening sequence is amplified. The result is a fingerprint that consists of different amplicons when separated on agarose gels. The major drawback of RAPD-PCR is its reproducibility. The use of a combination of primers in a single PCR and a selection of primer sequences, primer lengths and primer concentrations represent the parameters that can improve its reproducibility (Tyler et al., 1997).

Abufera et al. (2009) characterised Salmonella isolates according to the fingerprints obtained with RAPD-PCR, and their results showed correlation between these RAPD profiles and the serogroups. There were close similarities among human isolates, and also among animal isolates. McKnight et al. (2010) use RAPD-PCR for the analysis of Alicyclobacillus strains isolated from passion fruit juice, and they showed that Alicyclobacillus acidoterrestris was the prevalent strain in these fruit juices, irrespective of the different batches. A. acidoterrestris is the main Alicyclobacillus species associated with fruit-juice spoilage. As an indicator of ochratoxin A formation isolated from wheat flours, Penicillium verrucosum strains were grouped into separate groups according to their RAPD-PCR fingerprints, as were Penicillium nordicum reference strains, which suggests a direct application of this method (Cabanas et al., 2008). RAPD-PCR has also been used for differentiation of Penicillium expansum strains, as patulin-producing fungi (Elhariry et al., 2011). These strains were isolated from healthy appearing and rot-spotted apples, but genomic fingerprints showed that although strains were clustered into two separate groups, all of strains of $P$. expansum represented potential hazards. A modification of conventional RAPD-PCR is also seen with the application of melting-curve analysis to RAPD-generated DNA fragments (McRAPD) (Deschaght et al., 2010). 


\subsubsection{Repetitive-element PCR}

Repetitive-element (rep)-PCR is based on interspersed repetitive DNA elements of the repetitive extragenic palindrome and enterobacterial repetitive intergenic consensus, which are conserved throughout the eubacterial kingdom (Versalovic et al., 1991). The distribution and frequency of such repetitive DNA elements can be studied with PCR using outwardly directed primers that are specific for the repeat elements. If repeat elements are close enough to each other, amplification of the DNA sequences between them occurs (Versalovic et al., 1991). Rep-PCR products are then separated with agarose gel electrophoresis, and the fingerprints obtained are strain specific and can be used for typing. BOX elements represent another repetitive DNA element, which were introduced by van Belkum et al. (1996); these were also successfully used in rep-PCR. Automated rep-PCR technology is available as a commercial assay through the DiversyLab System ${ }^{\circledR}$, which does not require gel electrophoresis (Healy et al., 2005). The amplicons are separated using the microfluidics LabChip device, and they are detected using a bioanalyser. The resulting data are automatically collected and analysed using the DiversiLab software.

Although repetitive DNA elements were discovered in the genomes of E. coli and the Salmonella enterica serovar Typhimurium, these elements were subsequently found in several diverse Gram-negative and Gram-positive bacteria. All species of Listeria show repetitive elements of repetitive extragenic palindromes and enterobacterial repetitive intergenic consensus (Jeršek et al., 1996). Jeršek et al. (1999) showed that rep-PCR allowed the grouping of strains of L. monocytogenes according to their origins of isolation (clinical, animal and food origins). Indeed, according to rep-PCR fingerprints, Blatter et al. (2010) identified potential L. monocytogenes contamination sources in a sandwich-production plant. Finally, rep-PCR was also used for typing Aspergillus strains (Healey et al., 2004) for the determination of strain relatedness.

\subsubsection{Variable number of tandem repeat assay and its multiple-locus assay}

Variable number of tandem repeat (VNTR) assays use the variation in the number of tandem DNA repeats at a specific locus to distinguish between isolates (Keim et al., 2000). Short nucleotide sequences that are repeated several times often vary in the copy number that can be detected with PCR using flanking primers, thus creating length polymorphisms that can be strain specific. To increase the discrimination, Keim et al. (2000) developed the multiple-locus VNTR assay (MLVA). The VNTR and MLVA assays require knowledge of specific DNA sequences and the appropriate design of the primers to amplify the tandem DNA repeats. The PCR products can be separated and detected on agarose gels, and the fingerprints thus produced are analysed. The other possibility is to use fluorescently labelled primers that allow the PCR products to be electrophoretically analysed with an automated capillary DNA sequencer (Keim et al., 2000). Recently, there have been a number of studies that have used VNTR and MLVA for the genotyping of different strains. Keim et al. (2000) developed an MLVA assay for typing Bacillus anthracis strains, where they used eight genetic loci that allowed the typing of 426 isolates, which were divided into 89 MLVA genotypes. Cluster analysis of the fingerprints identified six genetically distinct groups, with some of these types showing a worldwide distribution, and others restricted to particular 


\begin{tabular}{|c|c|c|c|c|}
\hline $\begin{array}{l}\text { Food } \\
\text { component }\end{array}$ & Target & PCR & $\begin{array}{l}\text { Genetic marker (specific } \\
\text { amplicon) }\end{array}$ & Detection lin \\
\hline \multirow{3}{*}{ Allergen } & $\begin{array}{l}\text { Hazelnut } \\
\text { (Corylus spp.) }\end{array}$ & qPCR & Cor a 1 hazelnut gene (82 bp) & $0.1 \mathrm{ng}$ \\
\hline & $\begin{array}{l}\text { Celery } \\
\text { (Apium graveolens) }\end{array}$ & qPCR & $\begin{array}{l}\text { Mannose-6-phosphate } \\
\text { reductase mRNA (77 bp) }\end{array}$ & $\begin{array}{l}10 \mathrm{pg}, \mathrm{LOD} 0 \\
\text { celery }\end{array}$ \\
\hline & $\begin{array}{l}\text { Lupin (Lupinus), } \\
\text { soya (Glycine max) }\end{array}$ & $\begin{array}{l}\text { Duplex } \\
\text { PCR }\end{array}$ & $\begin{array}{l}\text { Mitochondrial tRNA-MET } \\
\text { gene (168 bp, } 175 \mathrm{bp})\end{array}$ & $\begin{array}{l}0.001 \mathrm{ng} ; 2.5 \\
\mathrm{~kg} \text { food matr }\end{array}$ \\
\hline \multirow[t]{2}{*}{ Mycotoxin } & $\begin{array}{l}\text { Aflatoxigenic } \\
\text { Aspergillus spp. }\end{array}$ & mPCR & $\begin{array}{l}\text { Structural genes omtB (1333 } \\
\text { bp), omt } A \text { (1032 bp), ver-1 (895 } \\
\text { bp), and regulatory gene aflR } \\
(797 \mathrm{bp})\end{array}$ & $\begin{array}{l}125 \mathrm{pg} / \mu \mathrm{L}, 1 \\
\text { spores/g me }\end{array}$ \\
\hline & $\begin{array}{l}\text { Patulin producing } \\
\text { Aspergillus and } \\
\text { Penicillim spp. }\end{array}$ & PCR & $\begin{array}{l}\text { Isoepoxydon dehydrogenase } \\
(\mathrm{idh}) \text { gene }(496 \mathrm{bp})\end{array}$ & $\begin{array}{l}0.5 \mathrm{ng} \text { DNA, } \\
\text { to } 2.7 \times 10^{3} \text { cor } \\
\text { in foods }\end{array}$ \\
\hline \multirow[t]{2}{*}{$\begin{array}{l}\text { Authenticit } \\
\mathrm{y}\end{array}$} & $\begin{array}{l}\text { Cattle and buffalo } \\
\text { milk }\end{array}$ & $\begin{array}{l}\text { Duplex } \\
\text { qPCR }\end{array}$ & $\begin{array}{l}\text { Mitochondrial D loop region of } \\
\text { cattle, buffalo (126 bp, } 226 \mathrm{bp})\end{array}$ & $\begin{array}{l}0.15 \text { ng buffa } \\
\text { ng cattle DN } \\
\text { adulteration } \\
\text { and buffalo n }\end{array}$ \\
\hline & Beef meat & qPCR & $\begin{array}{l}\text { Bovine-specific cytochrome b } \\
\text { gene }(c y t b)(116 \mathrm{bp})\end{array}$ & 35 pg bovine \\
\hline \multirow{2}{*}{$\begin{array}{l}\text { Bacterial } \\
\text { toxin }\end{array}$} & $\begin{array}{l}\text { Staphylococcal } \\
\text { enterotoxins in } \\
\text { food samples }\end{array}$ & qPCR & $\begin{array}{l}\text { Sea, seb, sec, sed genes of } S \text {. } \\
\text { aureus }\end{array}$ & ND \\
\hline & $\begin{array}{l}\text { Toxinogenic } B \text {. } \\
\text { cereus }\end{array}$ & $\begin{array}{l}\text { Multiplex } \\
\text { qPCR }\end{array}$ & $\begin{array}{l}\text { Genes of toxins (nheA, hblD } \\
\text { and cytK1) and emesis (ces) }\end{array}$ & $\begin{array}{l}10 \mathrm{CFU} / \mathrm{g} \text { aft } \\
\text { overnight } \\
\text { enrichment }\end{array}$ \\
\hline
\end{tabular}


geographic regions. MLVA assays were successfully used for typing L. monocytogenes strains using six specific genetic loci (Chen et al., 2011). The MLVA assay discriminated between outbreak isolates and unrelated food, animal and environmental isolates, with identical MLVA patterns seen for known outbreak-related isolates. The typing of L. monocytogenes strains with MLVA was also optimised for direct application to food samples. Differentiation of $S$. aureus strains isolated from raw milk and dairy products with MLVA using six tandem repeat loci grouped the strains into seven clusters that revealed clear genomic variability among the strains tested. MLVA assays with eight genetic loci were also developed for Brucella melitensis and Brucella abortus, which has enabled strain identification and the establishment of source of infection in several cases (Rees et al., 2009).

In the implementation of different typing methods, different parameters need to be considered; i.e. stability, discriminatory power, typing ability, reproducibility and agreement (Belkum et al., 2007). For practical reasons, the cost and availability of equipment also need to be considered.

\subsection{PCR as a tool for analysis of trace components in foods}

In recent years, PCR technology has been brought into use in other areas of the analysis of foods, such as for the authenticity of food, for food allergens, and for the indirect determination of bacterial toxins and mycotoxins. PCR offers possibilities for these food analyses as the DNA target for this reaction is a very stable and long-live molecule that is present in all organisms. The main problem for these assays is the preparation of the food sample for the analysis, as the concentrations of these unwanted compounds are usually very low. Thus the DNA extraction method has to be very effective to provide a relatively high yield of the target DNA for PCR. The other problem is the standards that are needed as control samples in all cases where qPCR is applied. However, some examples of recently applied assays are listed in Table 3.

\section{Conclusion}

PCR as a new technique that since its development in 1983 has reached many areas in a short period of time, including that of food analysis. Multiple use of PCR has been most pronounced in the field of food microbiology, although in recent years, PCR has been increasingly used in other areas, such as food hygiene, food toxicology and food analysis. Therefore, this chapter can only provide a brief summary of the various studies and applications of PCR and qPCR in the food industry.

\section{References}

Abufera, U.; Bhugaloo-Vial, P.; Issack, M. I. \& Jaufeerally-Fakim, Y. (2009). Molecular characterization of Salmonella isolates by REP-PCR and RAPD analysis. Infection, Genetics and Evolution, Vol. 9, No. 3, (May, 2009), pp. 322-327

Agersborg, A.; Dahl, R. \& Martinez, I. (1997). Sample preparation and DNA extraction procedures for polymerase chain reaction identification of Listeria monocytogenes in seafoods. International Journal of Food Microbiology, Vol. 35, No. 3, (December, 1997), pp. $275-280$ 
Akiba, M.; Kusumoto, M. \& Iwata, T. (2011). Rapid identification of Salmonella enterica serovars, Typhimurium, Choleraesuis, Infantis, Hadar, Enteritidis, Dublin and Gallinarum, by multiplex PCR. Journal of Microbiological Methods, Vol. 85, No. 1, (April, 2011), pp. 9-15

Al-Soud, W. A. \& Rådström, P. (2000). Effects of amplification facilitators on diagnostic PCR in the presence of blood, feces, and meat. Journal of Clinical Microbiology, Vol. 38, No. 12, (December, 2000), pp. 4463-4470

Aprodu, I.; Walcher, G.; Schelin, J.; Hein, I.; Norling, B.; Rådström, P.; Nicolau, A. \& Wagner, M. (2011). Advanced sample preparation for the molecular quantification of Staphylococcus aureus in artificially and naturally contaminated milk. International Journal of Food Microbiology, Vol. 145, No. 1, (March, 2011), pp. 61-65

Arlorio, M.; Cereti, E.; Coïsson, J.D.; Travaglia, F. \& Martelli, A. (2007). Detection of hazelnut (Corylus spp.) in processed foods using real-time PCR. Food Control, Vol. 18, No. 2, (February, 2007), pp. 140-148

Bai, J.; Shi, X. \& Nagaraja, T.G. (2010). A multiplex PCR procedure for the detection of six major virulence genes in Escherichia coli O157:H7. Journal of Microbiological Methods, Vol., 82, No. 1, (July, 2010), pp. 85-89

Bailey, J. S. (1998). Detection of Salmonella cells within 24 to 26 hours in poultry samples with the polymerase chain reaction BAX system. Journal of Food Protection, Vol. 61, No. 7, July 1998), pp. 792-795

Bartlett, J. M. S. \& Stirling, D. (2003). A short history of the polymerase chain reaction. In Methods in Molecular Biology, PCR Protocols, Humana Press, Vol. 226, 2 edition., (2003), pp. 3-6

Beutler, E.; Gelbart, T. \& Kuhl, W. (1990). Interference of heparin with the polymerase chain reaction. BioTechniques, Vol. 9, No. 2, (August, 1990), pp. 166

Bickley, J.; Short, J.K.; McDowell, D.G. \& Parkes, H.C. (1996). Polymerase chain reaction (PCR) detection of Listeria monocytogenes in diluted milk and reversal of PCR inhibition caused by calcium ions. Letters in Applied Microbiology, Vol. 22, No. 2, (February, 1996), pp. 153-158

Blatter, S.; Giezendanner, N.; Stephan, R. \& Zweifel, C. (2010). Phenotypic and molecular typing of Listeria monocytogenes isolated from the processing environment and products of a sandwich-producing plant. Food Control, Vol. 21, No. 11, (April, 2010), pp. 1519-1523

Brock biology of microorganisms. 2000. 9th ed. Madigan M. T.; Martinko J. M. \& Parker J. (eds.). Upper Saddle River, Prentice Hall International, pp. 33-40; 172-177

Brock, T. D. \& Boylen, K. L. (1973). Presence of thermophilic bacteria in laundry and domestic hot-water heaters. Applied Microbiology, Vol. 25, No. 1, (June, 1973), pp. $72-$ 76

Bustin, S. A. \& Nolan, T. (2004). Pitfalls of quantitative real-time reverse-transcription polymerase chain reaction. Journal of Biomolecular Techniques, Vol. 15, No. 3, (September, 2004), pp. 155-166

Bustin, S. A. (2004). A-Z of quantitative PCR. International University line, La Jolla, California, (2004), pp. 5-26, 87-112, 244-245

Cabanas, R. ; Bragulat, M. R. ; Abarca, M. L. ; Castella, G. \& Cabanes, F. J. (2008). Occurrence of Penicillium verrucosum in retail wheat flours from the Spanish market. Food 
Chen, S.; Li, J.; Saleh-Lakha, S.; Allen, V. \& Odumeru, J. (2011). Multiple-locus variable number of tandem repeat analysis (MLVA) of Listeria monocytogenes directly in food samples. International Journal of Food Microbiology, Vol. 148, No. 1, (July, 2011), pp. 8-14

Chien, A.; Edgar, D. B. \&, Trela, J. M. (1976) Deoxyribonucleic acid polymerase from the extreme thermophile Thermus aquaticus. Journal of Bacteriology, Vol. 127, No. 3, (September, 1976), pp. 1550-1557

Dahlenborg, M.; Borch, E. \& Rådström, P. (2001). Development of a combined selection and enrichment PCR procedure for Clostridium botulinum types B, E and F and its use to determine prevalence in fecal samples from slaughter pigs. Applied and Environmental Microbiology, Vol. 67, No. 10, (October, 2001), pp. 4781-4789

De Medici, D., L.; Croci, E.; Delibato, S.; Di Pasquale, E. \& Toti. L. (2003). Evaluation of DNA extraction methods for use in combination with SYBR Green I real-time PCR to detect Salmonella enterica serotype Enteritidis in poultry. Applied and Environmental Microbiology, Vol. 69, No. 6, (June, 2001), pp. 3456-3461

de Wet, S. C.; Denman, S. E.; Sly, L. \& McSweeney, C. S. (2008). An improved method for RNA extraction from carcass samples for detection of viable Escherichia coli O157:H7 by reverse-transcriptase polymerase chain reaction. Letters in Applied Microbiology, Vol. 47, No. 5, (November, 2008), pp. 399-404

De, S.; Brahma, B.; Polley, S.; Mukherjee, A.; Banerjee, D.; Gohaina, M.; Singh, K. P.; Singh, R.; Datta, R. K. \& Goswami, S. L. (2011). Simplex and duplex PCR assays for species specific identification of cattle and buffalo milk and cheese. Food Control, Vol. 22, No. 5, (May, 2011), pp. 690-696

Deschaght, P.; Van Simaey, L.; Decat, E.; Van Mechelen, E.; Brisse, S. \& Vaneechoutte, M. (2010). Rapid genotyping of Achromobacter xylosoxidans, Acinetobacter baumannii, Klebsiella pneumoniae, Pseudomonas aeruginosa and Stenotrophomonas maltophilia isolates using melting curve analysis of RAPD-generated DNA fragments (McRAPD). Research in Microbiology, Vol. 162, No. 4, (May, 2011), pp. 386-392

Elhariry, H.; Bahobial,A. A. \& Gherbawy, Y. (2011). Genotypic identification of Penicillium expansum and the role of processing on patulin presence in juice. Food and Chemical Toxicology, Vol. 49, No. 4, (April, 2011), pp. 941-946

Estrada, C. S. M. L.; Velázquez, L. C.; Escudero, M. E.; Favier, G. I.; Lazarte, V. \& Stefanini de Guzmán, A. M. (2011). Pulsed field, PCR ribotyping and multiplex PCR analysis of Yersinia enterocolitica strains isolated from meat food in San Luis Argentina. Food Microbiology, Vol. 28, No. 1, (February, 2011), pp. 21-28

Fahle, G. A. \& Fischer, S. H. (2000). Comparison of six commercial DNA extraction kits for recovery of cytomegalovirus DNA from spiked human specimens. Journal of Clinical Microbiology, Vol. 38, No. 10, (October, 2000), pp. 3860-3863

Freise, J.; Gerard, H. C.; Bunke, T.; Whittum-Hudson, J. A.; Zeidler, H.; Köhler, L.; Hudson, A. P. \& Kuipers, J. G. (2001). Optimised sample DNA preparation for detection of Chlamydia trachomatis in synovial tissue by polymerase chain reaction and ligase chain reaction. Annals of the Rheumatic Diseases, Vol. 60, No. 2, (February, 2001), pp. 140-145

Fuchs, M.; Cichna-Markl, M. \& Hochegger, R. (2012).Development and validation of a novel real-time PCR method for the detection of celery (Apium graveolens) in food. Food Chemistry, Vol. 130, No. 1, (January, 2012), pp. 189-195 
Galan, A. M. G.; Brohée, M.; de Andrade Silva, E.; van Hengel, A. J. \& Chassaigne, H. (2011). Development of a real-time PCR method for the simultaneous detection of soya and lupin mitochondrial DNA as markers for the presence of allergens in processed food. Food Chemistry, Vol. 127, No. 2, (July, 2011), pp. 834-841

Germini, A.; Masola, A.; Carnevali, P. \& Marchelli, R. (2009). Simultaneous detection of Escherichia coli O175:H7, Salmonella spp., and Listeria monocytogenes by multiplex PCR. Food Control, Vol. 20, No. 8, (August, 2009), pp. 733-738

Hahm, B. K. ; Maldonadob, Y.; Schreiberc, E.; Bhuniab, A. K. \& Nakatsu, C. H. (2003). Subtyping of foodborne and environmental isolates of Escherichia coli by multiplexPCR, rep-PCR, PFGE, ribotyping and AFLP. Journal of Microbiological Methods, Vol. 53, No. 3, (June, 2003), pp. 387- 399

Hallier-Soulier, S. \& Guillot, E. (1999). An immunomagnetic separation polymerase chain reaction assay for rapid and ultra-sensitive detection of Cryptosporidium parvum in drinking water. FEMS Microbiological Letters, Vol. 176, No. 2, (June, 1999), pp. 285289

Healy, M.; Huong, J.; Schrock, R ; Manry, J.; Renwick, A ; Nieto, R ; Woods, C.; Versalovic, J. \&. Lupski, J. (2005). Microbial DNA typing by automated repetitive-sequencebased PCR. Journal of Clinical Microbiology, Vol.43, No.1, (October, 2005), pp. 199207

Higuchi, R.; Dollinger, G.; Walsh, P. S. \& Griffith, R. (1992). Simultaneous amplification and detection of specific DNA sequences. Biotechnology, Vol. 10, No. 4, (April, 1992), pp. 413-417

Higuchi, R.; Fockler, C.; Dollinger, G. \& Watson, R. (1993). Kinetic PCR: Real time monitoring of DNA amplification reactions. Biotechnology, Vol. 11, No. 119, (September, 1993), pp. 1026-1030

Hill, W. E. (1996). The polymerase chain reaction: applications for the detection of foodborne pathogens. Critical Reviews in Food Science and Nutrition, Vol. 36, No. 1-2, (January, 1996), pp. 123-173

Holland, P. M.; Abramson, R. D.; Watson, R. \& Gelfand, D. H. (1991). Detection of specific polymerase chain reaction product by utilizing the $5^{\prime}$ to $3^{\prime}$ exonuclease activity of Thermus aquaticus DNA polymerase. Proceedings of the National Academy of Sciences USA, Vol. 88, No. 16, (August, 1991), pp. 7276-7280

Hoppe, B. L.; Conti-Tronconi, B. M. \& Horton, R. M. (1992). Gel-loading dyes compatible with PCR. BioTechniques, Vol. 12, No. 5, (May, 1992), pp. 679-680

Hudson, J. A.; Lake, R. J.; Savill, M. G.; Scholes P. \& McCormick, R. E. (2001). Rapid detection of Listeria monocytogenes in ham samples using immunomagnetic separation followed by polymerase chain reaction. Journal of Applied Microbiology, Vol. 90, No. 4, (April, 2001), pp. 614-621

Jaimes, C. P.; Aristizábal, F. A.; Bernal, M. M.; Suárez, Z. R. \& Montoya, D. (2006). AFLP fingerprinting of Colombian Clostridium spp. strains, multivariate data analysis and its taxonomical implications. Journal of Microbiological Methods, Vol. 67, No. 1, (Ocrober, 2006), pp. 64-69

Jeršek, B.; Gilot, P.; Gubina, M.; Klun, N.; Mehle, J.; Tcherneva, E.; Rijpens, N. \& Herman, L. Typing of Listeria monocytogenes strains by repetitive element sequence-based PCR. Journal of Clinical Microbiology, Vol. 37, No. 1, (January, 1999), pp. 103-109 
Jeršek, B.; Tcherneva, E.; Rijpens, N. \& Herman L. (1996). Repetitive element sequence-based PCR for species and strain discrimination in the genus Listeria. Letters in Applied Microbiology, Vol. 23, No. 1, (July, 1996), pp. 55-60

Jothikumar, N.; Kang, G. \& Hill, V. R. (2009). Broadly reactive TaqMan® assay for real-time RT-PCR detection of rotavirus in clinical and environmental samples. Journal of Virological Methods, Vol. 155, No. 2, (February, 2009), pp. 126-131

Kainz, P. 2000. The PCR plateau phase-Towards an understanding of its limitations. Biochimica et Biophysica Acta, Vol. 1494, No. 1-2, (November, 2000), pp. 23-27

Kanki, M.; Sakata, J.; Taguchi, M.; Kumeda, Y.; Ishibashi, M.; Kawai, T.; Kawatsu, K.; Yamasaki, W.; Inoue, K. \& Miyahara, M. (2009). Effect of sample preparation and bacterial concentration on Salmonella enterica detection in poultry meat using culture methods and PCR assaying of preenrichment broths. Food Microbiology, Vol. 26, No. 1, (February, 2009), pp. 1-3

Keim, P.; Price, L. B.; Klevytska, A. M.; Smith, K. L.; Schupp, J. M.; Okinaka, R.; Jackson, P.J. \& Hugh-Jones, M. E. (2000). Multiple-locus variable-number tandem repeat analysis reveals genetic relationships within Bacillus anthracis. Journal of Bacteriology, Vol. 182, No. 10, (May, 2000), pp. 2928-2936

Kérouanton, A.; Marault, M.; Petit, L.; Grout, J.; Dao, T. T. \& Brisabois, A. (2010). Evaluation of a multiplex PCR assay as an alternative method for Listeria monocytogenes serotyping. Journal of Microbiological Methods, Vol. 80, No.2, (February, 2010), pp. 134-137

Kim, C. H.; Khan, M.; Morin, D. E.; Hurley, W. L.; Tripathy, D. N.; Kehrli M.Jr.; Oluoch A. O. \& Kakoma, I. (2001). Optimization of the PCR for detection of Staphylococcus aureus nuc gene in bovine milk. Journal of Dairy Scienece, Vol. 84, No. 1, (January, 2001), pp. 74-83

Kim, D. M.; Chung, S. H. \& Chun, H. S. 2011. Multiplex PCR assay for the detection of aflatoxigenic and non-aflatoxigenic fungi in meju, a Korean fermented soybean food starter. Food Microbiology, Vol. 28, No. 7, (October, 2011), pp. 1402-1408

King, C. E.; Debruyne1, R.; Kuch, M; Schwarz, C. \& Poinar, H. N. (2009). A quantitative approach to detect and overcome PCR inhibition in ancient DNA extracts. Research Reports, Vol. 47, No. 5, (November, 2009), pp. 941-949

Klančnik, A.; Smole Možina, S. \& Jeršek, B. (2003). The effect of DNA preparation procedure on sensitivity of PCR detection of Listeria monocytogenes. Zbornik Biotehehniške fakultete, Vol. 81, No. 1, (May, 2003), pp. 65-73

Krämer, N.; Löfström, C.; Vigre, H.; Hoorfar, J.; Bunge, C. \& Malorny, B. (2011). A novel strategy to obtain quantitative data for modelling: Combined enrichment and realtime PCR for enumeration of salmonellae from pig carcasses. International Journal of Food Microbiology, Vol. 145, No. 1, (March, 2011), pp. 86-95

Kreader, C. A. (1996). Relief of amplification inhibition in PCR with bovine serum albumin or T4 gene 32 protein. Applied and Environmental Microbiology, Vol. 62, No. 3, (March, 1996), pp. 1102-1106

Kure, C. F.; Skaara, I.; Holst-Jensena, A. \& Abeln, E. C. A. (2003). The use of AFLP to relate cheese-contaminating Penicillium strains to specific points in the production plants. International Journal of Food Microbiology, Vol. 83, No. 2, (June, 2003), pp. 195-204 
Lantz, P. G.; Abu Al-Soud, W.; Knutsson, R.; Hahn-Hägerdal, B. \& Rådström, P. (2000). Biotechnical use of the polymerase chain reaction for microbiological analysis of biological samples. Biotechnology Annual Review, Vol. 5, pp. 87-130

Lantz, P. G.; Hahn-Hägerdal, B. \& Rådström, P. (1994). Sample preparation methods in PCRbased detection of food pathogens. Trends in Food Science and Technology, Vol. 5, No. 12, (December, 1994), pp. 384-389

Lantz, P. G.; Matsson, M.; Wadström, T. \& Rådström, P. (1997). Removal of PCR inhibitors from human faecal samples through the use of an aqueous two phase system for sample preparation prior to PCR. Journal of Microbiological Methods, Vol. 28, No. 3, (March, 1997), pp. 159-167

Lantz, P. G.; Tjerneld, F.; Hahn-Hägerdal, B. \& Rådström, P. (1996). Use of aqueous twophase systems in sample preparation for polymerase chain reactionbased detection of microorganisms. Journal of Chromatography. B, Biomedical Applications, Vol. 680, No. 1-2, (May, 1996), pp. 165-170

Lawyer, F. C.; Stoffels, S.; Saiki, R. K.; Chang, S. Y.; Landre, P. A.; Ambrason, R. D. \& Gelfand, D. H. (1993). High-level expression, purification, and enzymatic characterization of full-length Thermus aquaticus DNA polymerase. PCR Methods Appl., Vol. 2, No. 4, (May, 1993), pp. 275-287

Lee, J. L. \& Levin, R. E. (2011). Detection of 5 CFU/g of Escherichia coli O157:H7 on lettuce using activated charcoal and real-time PCR without enrichment. Food Microbiology, Vol. 28, No. 3, (May, 2011), pp. 562-567

Lee, M. D. \& Fairchild, A. (2006). Sample Preparation for PCR, In: PCR Methods in Foods, J. Maurer (Ed.), 41-50, Springer, ISBN-10: 0-387-28264-5, Athens, GA, United States of America, 24.10.2011, Available from http:/ / www.springerlink.com/content/k4172w2414867830

Leung, K. T.; Mackereth, R.; Tien, Y.-C. \& Topp, E. (2004). A comparison of AFLP and ERICPCR analyses for discriminating Escherichia coli from cattle, pig and human sources. FEMS Microbiology Ecology, Vol. 47, No. 1, (January, 2004), pp. 111-119

Lindqvist, R.; Norling, B. \& Lambertz, S. T. (1997). A rapid sample preparation method for PCR detection of food pathogens based on buoyant density centrifugation. Letters in Applied Microbiology, Vol. 24, No. 4, (April, 1997), pp. 306-310

Löfström, C.; Schelin, J.; Norling, B.; Vigre, H.; Hoorfar, J. \& Rådström, P. (2010). Culture independent quantification of Salmonella enterica in carcass gauze swabs by flotation prior to real-time PCR. International Journal of Food Microbiology, Vol.145, No. 1, (March, 2010), pp. 103-109

Logan, J., Edwards, K. \&, Saunders, N. (2009). Real-Time PCR: Current Technology and Applications Caister Academic Press. Editor: Applied and Functional Genomics, Health Protection Agency, London. (2009), pp. 284

Lomonaco, S.; Nucera D.; Parisi, A.; Normanno, G. \& Bottero, M. T. (2011). Comparison of two AFLP methods and PFGE using strains of Listeria monocytogenes isolated from environmental and food samples obtained from Piedmont, Italy. International Journal of Food Microbiology, Vol. 149, No. 2, (September, 2011), pp. 177-182

Lukue, M. I.; Rodríguez, A.; Andrade, M. J.; Gordillo, R.; Rodríguez, M. \& Córdoba J. J. (2011). Development of a PCR protocol to detect patulin producing moulds in food products. Food Control, Vol. 22, No. 12, (December, 2011), pp. 1831-1838 
Lyamichev, V.; Brow, M. A. D. \& Dahlberg, J. E. (1993). Structure-specific endonucleolytic cleavage of nucleic acids by eubacterial DNA polymerases. Science, Vol. 260 No. 5109, (May, 1993), pp. 778-783

Martínez-Blanch, J. F.; Sánchez, G.; Garay, E. \& Aznar, R. (2009). Development of a real-time PCR assay for detection and quantification of enterotoxigenic members of Bacillus cereus group in food samples. International Journal of Food Microbiology, Vol. 135, No. 30, (July, 2009) pp.15-21

Mayrl, E.; Roeder, B.; Mester, P.; Wagner, M. \& Rossmanith, P. (2009). Broad range evaluation of the matrix solubilization (matrix lysis) strategy for direct enumeration of foodborne pathogens by nucleic acids technologies. Journal of Food Protection, Vol. 72, No. 6, (June, 2009), pp. 1225-1233

McKillip, J. L.; Jaykus, L. A. \& Drake, M. A. (2000). A comparison of methods for the detection of Escherichia coli O157:H7 from artificially contaminated dairy products sing PCR. Journal of Applied Microbiology, Vol. 89, No. 1, (July, 2000), pp. 49-55

McKnight, I. C.; Eiroa, M. N. U.; Sant'Ana, A. S. \& Massaguer, P.R. (2010). Alicyclobacillus acidoterrestris in pasteurized exotic Brazilian fruit juices: Isolation, genotypic characterization and heat resistance. Food Microbiology, Vol. 27, No. 8, (December, 2010), pp. 1016-1022

Opel, K. L.; Chung, D. \& McCord, B. R. (2010). A study of PCR inhibition mechanisms using real time PCR. Journal of Forensic Sciences, Vol. 55, No. 1, (January, 2010), pp. 25-33

Perry, L.; Heard, P.; Kane, M.; Kim, M.; Savikhin, S.; Domínguez, W. \& Applegate, B. (2007). Application of multiplex polymerase chain reaction to the detection of pathogens in food. Journal of Rapid Methods and Automation in Microbiology, Vol. 15, No. 2, (June, 2007), pp. 176-198

Piskernik, S.; Klančnik, A.; Toplak, N.; Kovač, M. \& Jeršek, B. (2010). Rapid detection of Escherichia coli O157:H7 in food using enrichment and real-time polymerase chain reaction. Journal of Food and Nutrition Research, Vol. 49, No. 2, pp. 78-84

Pomp, D. \& Medrano, J. F. (1991). Organic solvents as facilitators of polymerase chain reaction. Biotechniques, Vol. 10, No. 1, (January, 1991), pp. 58-59

Postollec, F.; Falentin, H.; Pavan, S.; Combrisson. J. \& Sohier, D. (2011). Recent advances in quantitative PCR (qPCR) applications in food microbiology. Food Microbiology, Vol. 28, No. 5, (August, 2011), pp. 50-54

Rådström, P.; Knutsson, R.; Wolffs, P.; Lovenklev, M. \& Lofstrom, C. (2004). Pre-PCR processing strategies to generate PCR-compatible samples. Molecular Biotechnology, Vol. 26, No. 2, (February, 2004), pp. 133-146

Rådström, P.; Löfström, C.; Lövenklev, M.; Knutsson, R. \& Wolffs, P. (2008) Strategies for overcoming PCR inhibition. Cold Spring Harbor Protocols (doi:10.1101/pdb.top20)

Ramakers, C.; Ruijter, J. M.; Deprez, R. H. \& Moorman. A. F. (2003). Assumption-free analysis of quantitative real-time polymerase chain reaction (PCR) data. Neuroscience Letters, Vol. 339, No. 1, (March, 2003), pp. 62-66

Raymaekers, M.; Smets, R.; Maes, B. \& Cartuyvels, R. (2009). Checklist for optimization and validation of real-time PCR assays. Journal of Clinical Laboratory Analysis, Vol. 23, No. 3, (May, 2009), pp. 145-151

Rees, R. K.; Graves, M.; Caton, N.; Ely, J. M. \& Probert, W. S. (2009). Single tube identification and strain typing of Brucella melitensis by multiplex PCR. Journal of Microbiological Methods, Vol. 78, No. 1, (July, 2009), pp. 66-70 
Robyt, J. F. \& White, B. J. (1990). Biochemical Techniques Theory and Practice. Waveland Press, Inc., (1990), pp. 129-156

Rossen, L.; Nørskov, P.; Holmstrøm, K. \& Rasmussen, O.F. (1992). Inhibition of PCR by components of food samples, microbial diagnostic assays and DNA extraction solutions. International Journal of Food Microbiology, Vol. 17, No. 1, (September, 1990), pp. 37-45

Rutledge, R. G. \& Côté, C. (2003). Mathematics of quantitative kinetic PCR and the application of standard curves. Nucleic Acids Research, Vol. 31, No. 16, (May, 2009), pp. 1-6,

Saiki, R. K.; Gelfand, D. H.; Stoffel, S.; Scharf, S. J.; Higuchi, R.; Horn, G. T., Mullis, K. B. \& Erlich, H. A. (1988). Primer-directed enzymatic amplification of DNA with a thermostable DNA polymerase. Science, Vol. 239, No. 4839, (January, 1988), pp. 487-491

Saiki, R. K.; Scharf, S.; Faloona, F.; Mullis, K. B.; Horn, G. T.; Erlich, H. A. \& Arnheim, N. (1985). Enzymatic amplification of beta-globin genomic sequences and restriction site analysis for diagnosis of sickle cell anemia. Science, Vol. 230, No. 4732, (December, 1985), pp. 1350-1354

Sakai, F.; Takemoto; A.; Watanabe; S.; Aoyama; K.; Ohkubo; T.; Yanahira; S.; Igarashi; H.; Kozaki; S.; Hiramatsu; K. \& Ito; T. (2010). Multiplex PCRs for assignment of Staphylocoagulase types and subtypes of type VI Staphylocoagulase. Journal of Microbiological Methods, Vol. 75, No. 2, (October, 2010), pp. 312-317

Sambrook J. \& Russel D. W. (2001). Molecular Cloning: A Laboratory Manual 3rd Edition, Cold Spring Harbor Laboratory Press. Cold Spring Harbor, NY, (2001), pp. 5.4-5.14

Savelkoul; P. H. M.; Aarts; H. J. M.; DeHaas; J.; Dijkshoorn; L.; Duim; B.; Otsen; M. Rademarker; L. W.; Schouls; L. \& Lenstra; A. (1999). Amplified-Fragment Length Polymorphism Analysis: the State of an Art. Journal of Clinical Microbiology, Vol. 37; No. 10; (October, 1999), pp. 3083-3091

Silva, D. S. P.; Canato, T.; Magnani, M.; Alves, J.; Hirooka, E. Y.; Rocha, T. C. \& Moreira de Oliveira. T. C. R. M. (2011). Multiplex PCR for the simultaneous detection of Salmonella spp. \& Salmonella Enteritidis in food. International Journal of Food Science and Technology, Vol. 46, No. 7, (July, 2011), pp. 1502-1507

Steffan, R. J. \& Atlas R. M. (1991). Polymerase chain reaction - Applications in enviromental microbiology. Annual Review of Microbiology, Vol. 45, (October, 1991), pp. 137-161

Stewart, D. \& Gendel, S. M. (1998). Specificity of the bax polymerase chain reaction system for detection of the foodborne pathogen Listeria monocytogenes. Journal of AOAC International, Vol. 81, No. 4, (July-August, 1998), pp. 817-822

Stock, P.; Vanderberg, J.; Glazer, I. \& Boemare, N. (2009). 1.6.2. Primers development and virus identification strategies. Insect Pathogens: Molecular Approaches and Techniques. CAB International, (2009), pp. 22

Thisted Lambertz, S.; Lindqvist, R.; Ballagi-Pordány, A. \& Danielsson-Tham, M.-L. (2000). A combined culture and PCR method for detection of pathogenic Yersinia enterocolitica in food. International Journal of Food Microbiology, Vol. 57, No. 1-2, (June, 2000), pp. 63-73

Trnčíková, T.; Hrušková, V.; Oravcová, K; Pangallo, D. \& Kaclíková, K. (2009). Rapid and sensitive detection of Staphylococcus aureus in food using selective enrichment and 
real-time PCR targeting a new gene marker. Food Analytical Methods, Vol. 2, No. 4, (December, 2009), pp. 241-250

Trnčíková, T.; Piskernik, S.; Kaclikova, E.; Smole-Možina, S.; Kuchta, T. \& Jeršek, B. (2010). Characterization of Staphylococcus aureus strains isolated from food produced in Slovakia and Slovenia with regard to the presence of genes encoding for enterotoxins. Journal of Food and Nutrition Research, Vol. 49, No. 4, pp. 215-220

Tyler, K. D.; Wang, G.; Tyler, D. \& Johnson,W. M. (1997). Factors affecting reliability and reproducibility of amplification-based DNA fingerprinting of representative bacterial pathogens. Journal of Clinical Microbiology, Vol. 35; No.2, (February, 1997), pp. 339-346

Ulve, V. M.; Monnet, C.; Valence, F.; Fauquant, J.; Falentin, H. \& Lortal, S. (2008). RNA extraction from cheese for analysis of in situ gene expression of Lactococcus lactis. Journal of Applied Microbiology, Vol. 105, No. 5, (November, 2008), pp. 1327-1333

Uyttendaele, M.; van Boxstael, S. \& Debevere, J. (1999). PCR assay for detection of the E. coli O157:H7 eae-gene and effect of the sample preparation method on PCR detection of heat-killed E. coli O157:H7 in ground beef. International Journal of Food Microbiology, Vol. 52, No. 1-2, (November, 1999), pp. 85-95

van Belkum, A.; Sluijuter, M.; de Groot, R.; Verbrugh, H. \& Hermans, P. W. (1996). Novel BOX repeat PCR assay for high-resolution typing of Streptococcus pneumoniae strains. Journal of Clinical Microbiology, Vol. 34, No. 5, (May, 1996), pp. 1176-1179

van Belkum, A.; Tassios, P. T.; Dijkshoorn, L.; Haeggman, S.; Cookson, B.; Fry, N. K.; Fussing, V.; Green, J.; Feil, E.; Gerner-Smidt, P.; Brisse, S. \& Struelens, M. (2007). Guidelines for the validation and application of typing methods for use in bacterial epidemiology. Clinical Microbiology and Infectious Diseases, No. 13, Suppl. 3, (October, 2007), pp. 1-46

Versalovic, J.; Koeuth, T. \& Lupski, J. R. (1991). Distribution of repetitive DNA sequences in eubacteria and application to fingerprinting of bacterial genomes. Nucleic Acids Research, Vol. 19; No. 24, (November, 1991), pp. 6823 -6831

Warren, B. R.; Yuk, H. G. \& Schneider, K. R. (2007). Detection of Salmonella by flow-through immunocapture real-time PCR in selected foods within 8 hours. Journal of FoodProtection, Vol. 70, No. 4, (April, 2007), pp. 1002-1006

Wehrle, E.; Didier, A.; Moravek, M.; Dietrich, R. \& Märtlbauer, E. (2010). Detection of Bacillus cereus with enteropathogenic potential by multiplex real-time PCR based on SYBR green I. Molecular and Cellular Probes, Vol. 24, No. 3, (June, 2010), pp. 124-130, doi:10.1016/j.mcp.2009.11.004

Wehrle; E.; Moravek; M.; Dietrich; R.; Bürk; C.; Didie;r A. \& Märtlbauer; E. (2009). Comparison of multiplex PCR; enzyme immunoassay and cell culture methods for the detection of enterotoxinogenic Bacillus cereus. Journal of Microbiological Methods, Vol. 78, No. 3, (September, 2009), pp. 265-270

Weyant, R. S.; Edmonds, P. \& Swaminathan, B. (1990). Effect of ionic and nonionic detergents on the Taq polymerase. BioTechniques, Vol. 9, No. 3, (September. 1990), pp. 308-309

Whitehouse, C. A. \& Hottel, H. E. (2007). Comparison of five commercial DNA extraction kits for the recovery of Francisella tularensis DNA from spiked soil samples. Molecular and Cellular Probes, Vol. 21, No. 2, (April, 2007), pp. 92-96 
Williams, J. G.; Kubelik, A. R.; Livak, K. J.; Rafalski, J. A. \& Tingey, S. V. (1990). DNA polymorphisms amplified by arbitrary primers are useful as genetic markers. Nucleic Acids Research, Vol. 8, No. 22, (October, 1990), pp. 6531-6535

Wilson, I. G. (1997). Minireview: Inhibition and facilitation of nucleic acid amplification. Applied and Environmental Microbiology, Vol. 63, No. 10, (November, 1997), pp. 3741-3751

Wolffs, P. F. G.; Glencross, K.; Norling, B. \& Griffiths, M. W. (2007). Simultaneous quantification of pathogenic Campylobacter and Salmonella in chicken rinse fluid by a flotation and real-time multiplex PCR procedure. International Journal of Food Microbiology, Vol. 117, No. 1, (June, 2007), pp. 50-54

Wolffs, P. F. G.; Norling, B. \& Rådström, P. (2004). Rapid quantification of Yersinia enterocolitica in pork samples by a novel sample preparation method, flotation, prior to real-time PCR. Journal of Clinical Microbiology, Vol. 42, No. 3, (March, 2004), pp. 1042-1047

Zhang, C.-L.; Fowler, M. R.; Scott, N. W.; Lawson, G. \& Slater, A. (2007). A TaqMan realtime PCR system for the identification and quantification of bovine DNA in meats, milks and cheeses. Food Control, Vol. 18, No. 9, (September, 2007), pp. 1149-1158 


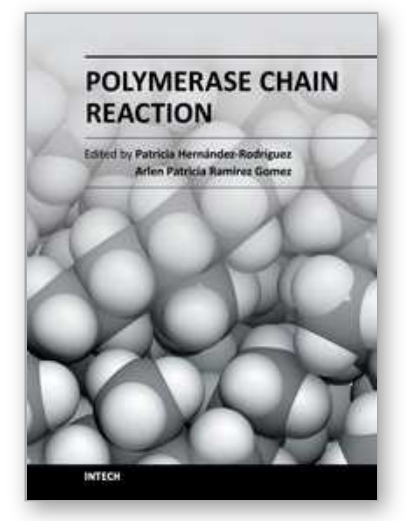

\author{
Polymerase Chain Reaction \\ Edited by Dr Patricia Hernandez-Rodriguez
}

ISBN 978-953-51-0612-8

Hard cover, 566 pages

Publisher InTech

Published online 30, May, 2012

Published in print edition May, 2012

This book is intended to present current concepts in molecular biology with the emphasis on the application to animal, plant and human pathology, in various aspects such as etiology, diagnosis, prognosis, treatment and prevention of diseases as well as the use of these methodologies in understanding the pathophysiology of various diseases that affect living beings.

\title{
How to reference
}

In order to correctly reference this scholarly work, feel free to copy and paste the following:

Anja Klancnik, Minka Kovac, Natasa Toplak, Sasa Piskernik and Barbara Jersek (2012). PCR in Food Analysis, Polymerase Chain Reaction, Dr Patricia Hernandez-Rodriguez (Ed.), ISBN: 978-953-51-0612-8, InTech, Available from: http://www.intechopen.com/books/polymerase-chain-reaction/pcr-in-food-analysis

\section{INTECH}

open science | open minds

\section{InTech Europe}

University Campus STeP Ri

Slavka Krautzeka 83/A

51000 Rijeka, Croatia

Phone: +385 (51) 770447

Fax: +385 (51) 686166

www.intechopen.com

\section{InTech China}

Unit 405, Office Block, Hotel Equatorial Shanghai

No.65, Yan An Road (West), Shanghai, 200040, China

中国上海市延安西路65号上海国际贵都大饭店办公楼405单元

Phone: +86-21-62489820

Fax: $+86-21-62489821$ 
(C) 2012 The Author(s). Licensee IntechOpen. This is an open access article distributed under the terms of the Creative Commons Attribution 3.0 License, which permits unrestricted use, distribution, and reproduction in any medium, provided the original work is properly cited. 